\title{
INVESTIGATING STUDENTS' ABILITY TO USE GERUND AND PRESENT PARTICIPLE AT ENGLISH EDUCATION DEPARTMENT OF SORONG MUHAMMADIYAH UNIVERSITY
}

\author{
Muhaiminah Akib \\ English Education Department, Faculty of Teacher Training and Education, Universitas \\ Muhammadiyah Sorong \\ Email: mina.akib@gmail.com
}

\begin{abstract}
Abstrak
This research presented analysing the students' ability to use gerund and present participle at English Education Department of Sorong Muhammadiyah University and the factors affecting the students' ability to use gerund and present participle. This research used descriptive method with the test and questionnaire instruments. The test consisted of 30 items and the questionnaire consisted of 23 items. The population of the research was the students of English Education Department of Sorong Muhammadiyah University in academic year 2011/2012 that consistent of 423 students. The sample of this research consisted of 43 students taken by applying purposive sampling technique.

The result of the data analysis indicated that the students' ability to use gerund and present participle was poor. It was indicated by the rate of percentage of the students' score obtained through in which out of 43 students, 3 students (7\%) got very poor score, 19 students $(44.2 \%)$ got poor score, 20 students (46.5\%) got fairly score, and $1(2.3 \%)$ students got good score. While none of them got very good score. The mean score of the test was 5.41 that falls into poor classification. The finding showed that the factors affected the students' ability to use gerund and present participle because the same form of gerund and present participle, the students did not know about the use of gerund and present participle and the students lack ability of memorizing.
\end{abstract}

Keywords: Ability, Gerund, Present Participle

\section{INTRODUCTION}

The field of grammar in learning English is wide enough, so we must classify the grammar into some topics to facilitate the English students in mastering it. One topic in grammar will relate to each other. So we must give attention to all topic in grammar although it seen simple. One of the familiar topics to the learner as well as the English teachers is the use of gerund and present participle.

\section{Gerund}

Grammarians define gerund as “-ing form used as noun”. As Betty (199: 150) stated that a gerund is the -ing form of a verb used as a noun. A gerund is used in the same way as a noun, as a subject or as an object. In the same way, in Cambridge ESOL 
Examinations, gerund defines as a form of a verb functioning as a noun, which ends in ing, e.g. I hate shopping.

\section{Present Participle}

Thompson and Martinet (1986: 228) stated that the gerund and present participle have the same form, ending -ing form. A present participle as a word has the function both of verb and adjective, and always ends in -ing form. Furthermore, Thompson and Martinet (1986: 239) explain that the present participle is formed by the infinitive + ing, e.g. working, loving. As Dykes (2007: 116) stated that the present participle is formed by adding -ing to the base verb form. For Turton, present participle is the -ing form of a verb.

The discussion of the use of gerund and present participle becomes important because it is basic of building an integrative comprehension concerning grammar. Many Indonesian students faced problem in the differentiating between gerund and present participle because gerund and present participle have the same form, as Thompson and Martinet (1986: 228) stated that the gerund and present participle have the same form, ending -ing form. The problem appears not only because gerund and present participle have the same form but also it is caused by their differences in function. In learning English, there are various factors that affect the learning ability of the students. The factors that affect the learning ability of the students are also important to know because some of these factors will affect the ability of the students positively and the other factors affect the students in a negative way. The importance of these factors is that the positive factors have to be reinforced and the negative factors have to be removed for the students so that the students can increase their learning ability.

Based on the explanation previous, the writer formulated research questions as follows: (1) How is the students' ability to use the gerund and present participle? (2) What factors affect the students' ability to use the gerund and present participle? 


\section{RESEARCH METHODOLOGY}

Population and Sample

The population of this research was the students of English Department of training and education faculty of Muhammadiyah University Sorong year 2011-2012 that consists of 423 students. The population in this research was 423 students; the number of sampling who the writer took was $10 \%$ from the population. So, the sample of this research was 43 students. The sample was taken by using purposive sampling.

\section{Research Instrument}

a. Test

In collecting data from the students about their ability, the researcher used the writing test. The test consisted of 30 numbers, 20 numbers are identification tests and 10 numbers are completion tests. The tests were intended to obtain data about the students' ability to use of Gerund and Present Participle.

b. Questionnaire

Students were required to respond to 23 statements. The questionnaire items were classified according to factors affecting the students' ability. The questionnaire consists of three sections:

1. Part A (items from 1 to 9): Individually

2. Part B (items from 10 to 16): Environment

3. Part C (items from 16 to 23): Learning Tasking

\section{FINDINGS AND DISCUSSIONS}

1. The Finding of the Data Analysis collected through the test

Forty three students of the fourth semester of English Education of Sorong Muhammadiyah University were taken as population in this research. The rate of the score of the fourth semester of English Education of Sorong Muhammadiyah University is shown as follows: 
Table 3

The rate percentage of the students' score obtained through the test

\begin{tabular}{clrrr}
\hline No. & Classification & Score & Frequency & Percentage \\
\hline 1. & Very good & $8.0-10$ & 0 & 0 \\
2. & Good & $6.6-7.9$ & 1 & 2.3 \\
3. & Fairly & $5.6-6.5$ & 20 & 46.5 \\
4. & Poor & $4.0-5.5$ & 19 & 44.2 \\
5. & Very Poor & $0.0-3.9$ & 3 & 7.0 \\
\hline & Total & & 43 & 100
\end{tabular}

Based on the data gained through the test, it was found that the level of ability of the fourth semester of English department of University of Muhammadiyah Sorong was poor. It was proved by the result of the data analysis through the test in which there were $3(7 \%)$ out of 43 students got very poor score, 19 (44.2\%) students got poor score, $20(46.5 \%)$ students got fairly score, and $1(2.3 \%)$ students got good score. While none of them got very good score.

Table 4

\begin{tabular}{llrr}
\multicolumn{3}{c}{ Statistic of Students' test result } & \\
\hline & Name & Value \\
N & 43 & 43 \\
& Malid & 0 & 0
\end{tabular}

Mean

5.4128

Furthermore, it was found that the mean score of the students was 5.41 which is classified poor score. It means the ability of fourth semester students of English department of Sorong Muhammadiyah University in using gerund and present participle is poor.

2. The findings of the data analysis collected through the questionnaire

The questionnaire distributed to 43 students consisted of 23 items. The data are presented in the form of descriptive statistic. 
Table 5

Individual Factors

\begin{tabular}{ccr}
\hline Items & Frequency & Percentage \\
\hline 1 & 42 & 97.6 \\
2 & 42 & 97.6 \\
3 & 41 & 95.4 \\
4 & 40 & 93 \\
6 & 10 & 23.2 \\
\hline & & 406.8 \\
\cline { 2 - 3 } & & $406.8: 23$ \\
& & $\mathbf{1 7 . 6 8}$
\end{tabular}

Table 5 illustrates that, among distributed items, 5 items represent the kinds of individual factor which affect the students ability. Those characteristic are such as:
a. Students' interest toward learning grammar
b. Students' participates actively in learning grammar
c. Learning gerund and present participle is important
d. Students' interest toward gerund and present participle
e. The frequency of learning gerund and present participle

Table 6

The Difficulties in learning gerund and present participle

\begin{tabular}{ccc}
\hline Items & Frequency & Percentage \\
\hline 5 & 36 & 83.8 \\
7 & 35 & 81 \\
8 & 31 & 72.1 \\
9 & 10 & 23.3 \\
\hline & & 260.2 \\
\cline { 2 - 2 } & & $260.2: 23$
\end{tabular}

\subsection{1}

a. Students found difficulties in differentiating between gerund and present participle 
b. The difficulty in learning gerund and present participle because they have same form

c. The difficulty in learning gerund and present participle because the student does not know about the use of gerund and present participle

d. The difficulty in learning gerund and present participle because the students does not know about the meaning of sentences

Table 7

Environment Factors

\begin{tabular}{ccc}
\hline Items & Frequency & Percentage \\
\hline 10 & 35 & 81 \\
11 & 42 & 97.6 \\
12 & 42 & 97.6 \\
13 & 39 & 90.7 \\
14 & 42 & 97.6 \\
15 & 36 & 83.8 \\
16 & 31 & 72.1 \\
\hline & & 624 \\
\hline & & $625: 23$
\end{tabular}

27.17

Table 7 illustrates that, among distributed items, 7 items represent the kinds of environment factor which affect the students ability. Those characteristic are such as:

a. The students asked the other if he/she is not understand about gerund and present participle.

b. The students asked the lecture if he/she is not understood about gerund and present participle.

c. The students asked the lecture to repeat the explanation about gerund and present participle if the student still not understood about them.

d. The students made reference to Grammar book if the students do not understand about gerund and present participle. 
e. The students interested to the teacher's explanation if the lecture explains directly.

f. The students interested to the teacher's explanation if the lecture divided the students to some groups then the student present the material.

Table 8

Learning Tasking Factors

\begin{tabular}{ccr}
\hline Items & Frequency & \multicolumn{1}{c}{ Percentage } \\
\hline 17 & 21 & 48.9 \\
18 & 19 & 44.2 \\
19 & 29 & 67.5 \\
20 & 36 & 83.8 \\
21 & 24 & 55.9 \\
22 & 27 & 62.8 \\
23 & 33 & 76.7 \\
\hline & & 439.8 \\
\hline & & $\mathbf{1 9 . 1 2}$ \\
\hline
\end{tabular}

Table 8 indicates that, among distributed items, 7 items represent the kinds of teachers' tasking factor which affect the students' ability. Those characteristic were such as:

a. The problem in learning gerund and present participle because the lack of the English book.

b. The problem in learning gerund and present participle because the lack of learning facilities.

c. The problem in learning gerund and present participle because the lack ability of students' memorizing.

d. The students did the task of gerund and present participle individually.

e. The students asked to their friends when he/she does the task about gerund and present participle.

f. The students practiced about gerund and present participle out class. 
g. The students applied grammar aspect specially gerund and present participle in their writing.

\section{Discussion}

1. The Discussion of the Findings through the Test

Based on the data gained through the test, there were 3 out of 43 students got very poor score, 19 students got poor score, 20 students got fairly score, and 1 student got good score. While none of them got very good score. Furthermore, it was found that the mean score of the students was 5.41. It means the ability of fourth semester students of English department of Sorong Muhammadiyah University in using gerund and present participle is poor.

The result of section B test, the researcher could conclude that many students not only confuse at verb form after preposition but they were still confused at appropriate preposition after some verb.

2. The Discussion on the Findings through the Questionnaire

From analyzing the data of questionnaire, the researcher found that the most students were very interested in learning grammar especially gerund and present participle. This was one of individual factors that affect the students' ability. This was in line with Helme and Clarke (2001) stating that students need to have both the will (motivation) and the skill (capability) to be successful learners. But the other hand, the high motivation from the students is not followed by the frequency of learning gerund and present participle. For the students, the frequency of learning gerund and present participle was not enough.

From the findings, students stated that the material of gerund and present participle was difficult to understand. It was supported by the result of data analysis in which of 43 students, the students answered through of gerund and present participle that the students were difficult to differ between gerund and present participle because of the same form of them and the students did not master the function of sentences. This was line with Nurhana's research (2009) at the Third Year Level of MA Perguruan Islam Syekh Yusuf Sungguminasa Gowa that tha 
factor faced by students in learning gerund and present participle is because the students did not mastery the function of the gerund and present participle.

About the learning model, the students would make reference to the grammar book if they do not understand about gerund and present participle. The students were interested if the lecture explained gerund and present participle directly. The students were also interested if the lecture divided the students to some group then the students present the material. It seems they feel more comfortable, productive, and relaxed by working in other ways, example in pairs, or in groups. This search contrast with Reid (1987) indicated that the most group showed a negative presence for learning. But on the other hand, the research showed that the students also interested in learning individually.

For the students, the lack of grammar books and learning facilities was not the problem in learning gerund and present participle, but the main problem in learning gerund and present participle for the students was caused the lack the their ability of memorizing. This research contrast with Nurhana's research (2009) that found that the students faced difficulties in differentiating gerund and present participle it was caused the students lack of English Book.

As a result from the questionnaire, the students more comfortable if they do task of gerund and present participle individually and part of them would ask to their friend when they do the task if they found the difficulties in their task.

The data also showed that the most of students practiced about gerund and present participle out class and apply this grammar aspect in their writing. But this fact could not help the student to get the high score in gerund and present participle tests. Their habits did not influence to their ability. This fact needed the more research from the other research to know what causal factor of this fact.

The last, researcher can conclude that the most influence factor to the students' ability is the individually factors that the students still difficult in differentiating gerund and present participle because the same form of them and the students did not know about the use of gerund and present participle. And the other was caused by the lack ability of memorizing of the students. 


\section{CONCLUSSION}

Based on the findings and discussion of the previous chapter, the study has come out with some conclusions, they are:

1. The students' ability of English Department of Sorong Muhammadiyah University was poor. It was provided by the result of the test in which the mean score of the students was 5.41. It fallen in to poor classification.

2. The factors affected the students' ability to use gerund and present participle, they were: the students found the difficulties in differentiating gerund and present participle, the students still difficult in differentiating gerund and present participle because the same form of them, the students did not know about the use of gerund and present participle and the students lack ability of memorizing.

\section{Bibliography}

Arikunto, S. 1984. Dasar-dasar Evaluasi Pendidikan, Jakarta; Bina Aksara.. . 1996. Prosedur Penelitian. Suatu Pendekatan Praktek. Edisi Revisi III. Jakarta; PT. Rineka Cipta..

Azar, Betty Schrampfer. 2000. Understanding and Using English Grammar, Third Edition. New York: Pearson Education.

Bryson, Bill. 2008. Bryson's Dictionary for Writers and Editors. New York: Broadway Books.

Carbon, Angela etc, An Exploration of Internal Factors Influencing Student Learning of Programming, Monash University, Australia.

Denscombe, Martyn. 2007. The Good Research Guide for small-scale social research projects Third Edition. London: Open University Press.

Dykes, Barbara. 2007. Grammar for Everyone: Practical Tools for Learning and Teaching Grammar. Victoria: ACER Press.

Examinations, Cambridge ESOL. Teaching Knowledge Test Glossary.

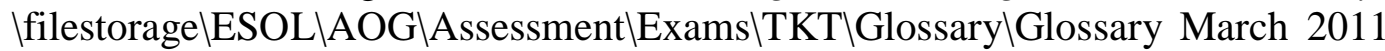
v2.doc.Greenbaum, Sidney and Gerald Nelson. 2002. An Introduction to English Grammar: Second Edition. Great Britain: Pearson Education Limited.

Filiz, Prof., Dr., 2005. An Analysis of the Relationship between the Use of Grammar Learning Strategies and Student Achievement at English Preparatory Class, Journal of Language and Linguistic Studies. Vol.1, No.2, October 2005. 
Greenbaum, Sidney and Gerald Nelson. 2002. An Introduction to English Grammar: Second Edition. Great Britain: Pearson Education Limited.

Harmer, Jeremy. 1987. Teaching and Learning Grammar. London: Longman.

Helme, S., \& Clarke, D. (2001). Identifying Cognitive Engagement in Mathematics Classroom. Mathematics Education Research Journal, 13, 133-153.

Jackson, Howard. 2005. Good Grammer for Students. London: Sage Publications.

Nugiyanto, 1998, Penilaian dalam Pengajaran Bahasa dan Sastra, Yogyakarta; BPEF.

Nunan, David, 2004, Task-Based Language Teaching, United Kingdom; Cambridge University Press.

Nurdin, Fahriani. 2007. The Difficulties Faced by the Second Year Students In Learning Gerund and Present Participle at Smun 1 Bajeng, A Thesis. Makassar: University of Muhammadiyah Makassar.

Nurhana, 2009. The Student Difficulties in Differentiating between the Use of Gerund and Present Participle of the Third Year Sudents of MA Perguruan Islam Syekh Yusuf Sungguminasa Gowa, a Thesis. Makassar: Universitas Islam Negeri Makassar.

Oxford Brookes University, 2005, Definition of Ability, Course Materials Unit 1 Section 1, Westminster Institute of Education, November 2005.

Reid, J. M. (1987). The Learning Ss tyle Preferences of ESL Students. TESOL Quarterly, 21, 87-111.

Savage, K. Lynn. 2010. Matters Teaching Grammar in Adult ESL Programs. New York: Cambridge University Press.

Sitanggang, Damianus P. 2008. The Ability Of The 2007 Year Students of English Literature Department, University of Sumatera Utara to Distinguish Present Participle from Gerund, A Thesis. Medan: University of Sumatera Utara.

Sutomo. 1985. Tekhnik Penelitian dan Pendidikan. Surabaya: Bina Ilmu.

Thomson, A. J. and A. V. Martinet, 1986, A Practical English Grammar. Oxford: Oxford University Press.

Turton, Nigel D. 1995. ABC of Common Grammatical Errors. London: Macmillan Publisher Limited. 